\title{
A PERSPECTIVA SEMIODISCURSIVA NOS GÊNEROS TELEVISIVOS DE INFORMAÇÃO: UMA ANÁLISE DOS GÊNEROS DISCURSIVOS EM LIBRAS DO ACERVO MULTIMÍDIA DA TV INES
}

\author{
Rosemeri Bernieri de Souza
}

Submetido em 31 de maio de 2019.

Aceito para publicação em 04 de julho de 2019.

Cadernos do IL, Porto Alegre, n. ${ }^{\circ}$ 59, outubro. p. 325-346.

\section{POLÍTICA DE DIREITO AUTORAL}

Autores que publicam nesta revista concordam com os seguintes termos:

(a) Os autores mantêm os direitos autorais e concedem à revista o direito de primeira publicação, com o trabalho simultaneamente licenciado sob a Creative Commons Attribution License, permitindo o compartilhamento do trabalho com reconhecimento da autoria do trabalho e publicação inicial nesta revista.

(b) Os autores têm autorização para assumir contratos adicionais separadamente, para distribuição não exclusiva da versão do trabalho publicada nesta revista (ex.: publicar em repositório institucional ou como capítulo de livro), com reconhecimento de autoria e publicação inicial nesta revista.

(c) Os autores têm permissão e são estimulados a publicar e distribuir seu trabalho online (ex.: em repositórios institucionais ou na sua página pessoal) a qualquer ponto antes ou durante o processo editorial, já que isso pode gerar alterações produtivas, bem como aumentar o impacto e a citação do trabalho publicado.

(d) Os autores estão conscientes de que a revista não se responsabiliza pela solicitação ou pelo pagamento de direitos autorais referentes às imagens incorporadas ao artigo. A obtenção de autorização para a publicação de imagens, de autoria do próprio autor do artigo ou de terceiros, é de responsabilidade do autor. Por esta razão, para todos os artigos que contenham imagens, o autor deve ter uma autorização do uso da imagem, sem qualquer ônus financeiro para os Cadernos do IL.

\section{POLÍTICA DE ACESSO LIVRE}

Esta revista oferece acesso livre imediato ao seu conteúdo, seguindo o princípio de que disponibilizar gratuitamente o conhecimento científico ao público proporciona sua democratização.

http://seer.ufrgs.br/cadernosdoil/index

Terça-feira, 29 de outubro de 2019. 


\title{
A PERSPECTIVA SEMIODISCURSIVA NOS GÊNEROS TELEVISIVOS DE INFORMAÇÃO: UMA ANÁLISE DOS GÊNEROS DISCURSIVOS EM LIBRAS DO ACERVO MULTIMÍDIA DA TV INES ${ }^{1}$
}

\author{
THE SEMIODISCURSIVE PERSPECTIVE IN THE \\ INFORMATIVE TELEVISION GENRES : AN ANALYSIS \\ OF THE DISCURSIVE GENRES IN LIBRAS OF THE \\ MULTIMEDIA COLLECTION OF INES TV
}

Rosemeri Bernieri de Souza*

\begin{abstract}
RESUMO: Os estudos sobre gêneros discursivos têm aumentado consideravelmente na atualidade, haja vista sua importância nos processos de agenciamento das práticas linguageiras nas várias esferas da vida sociocultural. Entretanto, pesquisas sobre os gêneros na materialidade da língua de sinais ainda são incipientes. Por isso, objetiva-se ao longo do presente artigo (a) apresentar a concepção semiodiscursiva de análises de gêneros (CHARAUDEAU, 2004); (b) discorrer sobre a proposta tipológica de gêneros televisivos informativos (CHARAUDEAU, 1997); e (c) explorar as possibilidades de análise documental de alguns videorregistros do acervo da TV INES, abordando, sobretudo, o telejornalismo, a reportagem e o debate. Portanto, este artigo mostra-se relevante, à medida que amplia a reflexão sobre a perspectiva semiodiscursiva para o webjornalismo e para os gêneros em língua de sinais, oferecendo subsídios para futuras investigações.
\end{abstract}

PALAVRAS-CHAVE: Libras; web TV; gêneros; abordagem semiodiscursiva.

ABSTRACT: Studies on discursive genres have increased considerably in the present time, given their importance in the processes of language-practices agency in the various spheres of sociocultural life. However, research on genres in sign language materiality is still incipient. Therefore, the objective of this article is (a) to present the semiodiscursive conception of gender analysis (CHARAUDEAU, 2004); (b) to discuss the typological proposal of informative television genres (CHARAUDEAU, 1997); and (c) to explore the possibilities of documentary analysis of some videorecords of the collection of TV INES, addressing, above all, the television journalism, reporting and debate. Therefore, this article is relevant, as it broadens the reflection on the semiodiscursive perspective for the genres in sign language and for the webjournalism, offering subsidies for future investigations.

KEYWORDS: Libras; web TV; genres; semiodiscursive approach.

\section{Introdução}

\footnotetext{
* Doutoranda do Programa de Pós-Graduação em Linguística da Universidade Federal de Santa Catarina, bernieri.rose@gmail.com

${ }^{1}$ O presente trabalho foi realizado com apoio da Coordenação de Aperfeiçoamento de Pessoal de Nível Superior - Brasil (CAPES) - Código de Financiamento 001

Agradecemos à equipe da Roquette Pinto pelos esclarecimentos a respeito da difusão das imagens que ilustram este trabalho.
} 
É inquestionável a importância dos gêneros discursivos para os processos de agenciamento das práticas linguageiras ${ }^{2}$ nas várias esferas da vida sociocultural. Por isso, o seu estudo é muito relevante, mas complexo, uma vez que abrange várias dimensões, como a ancoragem social, a natureza comunicacional, as atividades linguageiras propriamente ditas e as características formais implicadas na sua construção (CHARAUDEAU, 2004). A complexidade começa na própria noção de gênero que, ao longo do tempo, foi abordada de diferentes formas e perspectivas que privilegiaram ora uma, ora outra dimensão.

A noção de gênero, que é adotada neste trabalho, está circunscrita na perspectiva semiodiscursiva, para a qual os objetos apresentam constantes ou conjuntos de características, de forma que podem ser integrados em categorias. Conforme Charaudeau,

Um gênero, ou um tipo, é uma categoria determinada após um procedimento indutivo, de acordo com as propriedades internas que caracterizam certos objetos, e cujas semelhanças e diferenças permitem estabelecer agrupamentos e diferenciações (2012, p. 22, itálicos do autor, tradução nossa) ${ }^{3}$.

Ou seja, os gêneros discursivos, assim como outros objetos de mundo, podem ser considerados instâncias pertencentes a determinados domínios mais genéricos. Não se pode, portanto, confundir gênero com tipologia (domínio), visto que os termos estão em uma posição hierárquica distinta. Nas palavras desse mesmo autor,

\begin{abstract}
Uma tipologia, portanto, é um princípio de classificação que resulta de um procedimento dedutivo. Em vez de partir de uma descrição de objetos existentes, partimos de um conjunto de características que os definem como uma categoria e fazem comparações com outros objetos que formam outras categorias, para proceder a um agrupamento e uma distribuição deles de acordo com parâmetros diferenciadores (2012, p. 22, itálicos do autor, tradução nossa) $)^{4}$.
\end{abstract}

Assim, toda tipologia (domínio) pressupõe a existência de objetos (instâncias) que podem ser agrupados pelo fato de compartilharem determinados traços ou características. Por exemplo, a categoria jornalística (domínio ou tipo) pode conter diferentes gêneros como reportagem, entrevista, notícia, cujo critério fundante é trazer informação; a categoria jurídica pode abranger gêneros como petição, contestação, liminar etc., cuja finalidade principal é regular atos e processos jurídicos. As categorias jornalística e jurídica representam, de fato, dois dos setores de atividade social e os gêneros são tipos de textos que desempenham determinadas funções de base nas atividades linguageiras praticadas dentro desses domínios.

Outra distinção importante se refere aos critérios de composição e organização

\footnotetext{
${ }^{2} \mathrm{O}$ termo linguageiro, aqui entendido, remete ao envolvimento de diversas linguagens (verbais ou nãoverbais) para fins comunicativos e discursivos próprios das interações humanas.

${ }^{3}$ Do original: Un género, o un tipo, es una categoría determinada luego de un procedimiento inductivo, según las propiedades internas que caracterizan a ciertos objetos, y cuyas similitudes y diferencias permiten establecer agrupamientos y diferenciaciones.

${ }^{4}$ Do original: Una tipología, por tanto, es un principio de clasifi cación que resulta de um procedimento deductivo. En vez de partir de una descripción de los objetos existentes, se parte de un conjunto de características que los definen como categoria y se hacen comparaciones con otros objetos que forman otras categorías, para proceder a un agrupamiento y a una distribución de las mismas según parámetros diferenciadores.
} 
dos gêneros. Os textos são compostos por sequências ou, segundo Charaudeau (2012), por modos de organização do discurso, tais como o narrativo, o descritivo, o argumentativo etc. Um gênero é, então, um tipo de texto e não um tipo de procedimento discursivo (CHARAUDEAU, 1997).

Essas distinções são importantes, visto que há pelo menos três pontos que devem ser considerados: o primeiro é que um mesmo gênero pode ser encontrado em mais de uma categoria; o segundo é que as sequências textuais podem compor os mais variados gêneros e o terceiro se deve ao fato de que um mesmo gênero pode apresentar mais de uma sequência textual. Em outras palavras, a despeito dos exemplos dados, uma investigação mais aprofundada poderá demonstrar a dificuldade de inserir os gêneros em categorias estanques, sendo necessário abordá-los sob uma perspectiva diferente.

Dadas essas informações de base, vale complementar que o nosso objeto de investigação, os gêneros discursivos em Língua Brasileira de Sinais (Libras), fazem parte de um significante repertório de mídia digital. Esses objetos possuem uma materialidade híbrida, pois os conteúdos são construídos com textos bilíngues e multimodais (Libras, português falado e escrito), que são condicionados aos modos de produção, ao suporte e às finalidades discursivas do domínio televisivo.

Para o desenvolvimento deste trabalho, a seguinte questão de pesquisa foi levantada: os documentos multimídias da TV INES podem ser analisados de acordo com a proposta de Charaudeau $(1997 ; 2004)$, apesar de esse autor não ter abordado a Web TV nem a materialidade da língua de sinais? No intuito de responder a essa questão, adota-se uma abordagem de pesquisa qualitativa de natureza aplicada, cujo objetivo geral é investigar os gêneros informativos webtelevisivos em Libras, explorando as possibilidades de análise documental dos conteúdos audiovisuais da TV INES, com foco nos gêneros televisivos de informação, de acordo com suas características e especificidades.

Assim, o procedimento contará com uma seleção de documentos multimídias disponíveis no site www.tvines.org.br que servirão como dados para a investigação, os quais serão submetidos aos critérios teórico-metodológicos dos seguintes textos de Charaudeau: "As condições de uma tipologia dos gêneros televisivos de informação", de 1997 e "As visadas discursivas, gêneros situacionais e construção textual", publicado em francês em 2001 e traduzido em Português em 2004 (organizado por Ida Lúcia Machado e Renato de Mello) - textos esses que aparecem, em parte ou integralmente, em outras publicações em nome do autor, sobretudo no livro Discurso das Mídias, publicado pela Editora Contexto em 2006.

Este trabalho responde a uma problemática atual: a da escassez de estudos sobre gêneros discursivos em Libras. De fato, as pesquisas e discussões sobre a Libras giraram em torno da sua descrição estrutural, gramatical e lexical ou, de um ponto de vista mais sociolinguístico, da delimitação de seu status, das explicações sobre os fenômenos de variação e mudança, do contato linguístico com o português, entre outros temas afins. Essas abordagens foram e são imprescindíveis para aumentar o conhecimento sobre essa língua, porém, as pesquisas foram limitadas pela falta de dados para análises que tomassem a trama textual como ponto de partida. Com a recente ampliação da participação social do surdo e a evolução tecnológica, o acesso a discursos sinalizados está sendo expandido significantemente, sobretudo na internet.

Com efeito, a Web tem se revelado um terreno profícuo para a pesquisa linguística, mas essas mudanças, que são respostas às práticas sociais que se atualizam e se modernizam, impõem muitos desafios sobretudo em relação à heterogeneidade e 
diversidade de gêneros e seus novos modos de produção. Portanto, a escolha pela TV INES é justificada por ser esta uma grande fonte de dados passíveis de análise e inteiramente abertos e acessíveis ao espectador e ao pesquisador.

Criada em 2013 da parceria entre o Instituto Nacional de Educação de Surdos (INES) e a Roquette Pinto, a TV INES é uma iniciativa pioneira no Brasil que oferece o acesso à informação às pessoas surdas, uma vez que grande parte do conteúdo é realizado em Libras e outra parte interpretado para a Libras. Além disso, a narração em português e a legenda em português escrito possibilita o acesso aos espectadores nãosurdos ou surdos não-sinalizantes também. Os videorregistros são separados em seções e contêm informações sobre a atualidade nacional e internacional, sobre a cultura, literatura e o esporte, sobre curiosidades e fatos históricos, além de uma seção didática de ensino e aprendizagem de Libras. A equipe é formada por mais de 50 profissionais, dos quais seis são apresentadores surdos e cinco são intérpretes. ${ }^{5}$ Os conteúdos multimídias ali disponíveis podem fornecer informações sobre os modos de produção textual e discursiva, oferecendo a possibilidade de análise de diversos gêneros em Libras.

A escolha pelo aporte teórico de Charaudeau (1997, [2001] 2004) se justifica pelo fato de que, atualmente, ele pode ser considerado a principal autoridade no âmbito do discurso midiático, uma vez que, como analista do discurso, há tempo empreende estudos de discursos construídos em diferentes mídias, tendo, assim, sistematizado suas investigações em um quadro teórico de grande relevância.

A partir dessas informações introdutórias, o desenvolvimento desta pesquisa seguirá os seguintes passos: na seção 2 , serão discutidas as principais tendências de análise de gêneros dentro da perspectiva semiodiscursiva; na seção 3, serão condensados os principais pontos da proposta tipológica de gêneros discursivos informativos segundo o aporte teórico escolhido; na seção 4, será empreendida a análise de conteúdos multimídia da TV INES, quando serão definidas as possibilidades e diferenciações desses documentos em relação a outros ambientes que não contemplam a materialidade da língua de sinais; por fim, na seção 5, serão feitas as considerações finais.

\section{A tendência semiodiscursiva de análise de gêneros ${ }^{6}$}

$\mathrm{Na}$ introdução deste artigo, foram fornecidos alguns esclarecimentos sobre as definições de gênero, tipologia e sequência textual, marcando as distinções entre elas. Nesta seção, a problemática dos gêneros, que de todas é a mais complexa, será examinada sob o escopo da tendência semiodiscursiva (CHARAUDEAU, 1997, 1999, 2001, 2004, 2005, 2006, 2012; MAINGUENEAU, 2001, 2004), para a qual os gêneros são concebidos como

(a) rotinas/comportamentos estereotipados estabilizados e em variação contínua; (b) atividades/atos de linguagem submetidos a critérios de êxito finalidade, estatuto de parceiros, temporalidade, suporte material e organização textual; (c) contrato - pressupõe ser cooperativo e regido por normas sociais; (d) papel - implica a determinação de papéis sociais dos interactantes e (e) jogo - compreendem regras mutuamente conhecidas pelos

\footnotetext{
${ }^{5}$ Informações disponíveis em: http://roquettepinto.org.br/projetos/tv-ines/, acesso em 06 maio 2019.

${ }^{6}$ A menos que seja indicado, toda esta seção tem como base o texto de 2004 de Charaudeau.
} 
Os gêneros, enquanto rotinas, comportamentos, atividades, contrato, papel e jogo são internalizados no processo de socialização dos sujeitos. Haveria, assim, segundo a hipótese de Charaudeau (2004), três memórias que estão na base da constituição das comunidades: uma memória dos discursos que, em forma de conhecimentos, saberes e crenças, circulam na sociedade, constituindo-se em representações em torno das quais as identidades coletivas são construídas; uma memória das situações de comunicação que normatiza as trocas linguageiras; e uma memória das formas dos signos, responsável por regular e organizar a dinâmica dos modos de dizer mais ou menos rotineiros, segundo a variabilidade das trocas e do uso da comunidade.

Essas memórias estariam correlacionadas e articuladas entre si. Assim, inscritos no mundo dos signos em dadas circunstâncias sócio-históricas, os sujeitos sociais se dotam de gêneros empíricos, significando suas intenções e regulando seus modos de dizer, de acordo com os lugares e os papéis sociais que ocupam. Dentro dessa concepção psico-sócio-comunicativa, uma teoria do discurso precisa estar vinculada a uma teoria do fato linguageiro, cujos diferentes níveis de organização precisam ser determinados.

Os principais níveis de organização do fato linguageiro são: o dos princípios gerais, o dos mecanismos e o da situação de comunicação. Os princípios gerais têm por função fundar a atividade de linguagem e são divididos em: princípios de alteridade, de influência, de regulação e de pertinência (CHARAUDEAU, 1995). Assim, esses princípios, que orientam o ato de comunicação, legitimam a intencionalidade de acordo com (a) o grau de envolvimento e relação entre os interactantes, que são ora comunicantes, ora interpretantes do ato linguageiro; (b) o reconhecimento do universo de referência, dos valores psicológicos e sociais, a fim de que o ato linguageiro seja apropriado à situação de comunicação; (c) o uso de estratégias para evitar incompreensões que possam romper o ato comunicativo; (e) a finalidade e os efeitos que o ato comunicativo vai exercer sobre os interpretantes.

De acordo com Charaudeau (2004), o nível dos mecanismos do funcionamento do ato linguageiro ordena a discursivização (mise en discours), estruturando o domínio de prática em domínio de comunicação e pondo em relação todo o conjunto de procedimentos semiodiscursivos. O nível da situação de comunicação, por outro lado, é onde se "instituem as restrições que determinam a trama [enjeu] da troca" (1999, p. 8, tradução nossa), de acordo com a identidade e o lugar dos interactantes, bem como as finalidades que os engajam na troca comunicativa.

Alguns dos fios que tecem o ato linguageiro levam a denominação de visadas, que correspondem a uma intencionalidade psico-sócio-discursiva que determina a trama discursiva e as atitudes enunciativas. As visadas relacionam dois papéis que os interactantes podem desempenhar em dado contexto comunicativo. Desse modo, um sujeito "eu" comunicante, ocupando o lugar de enunciador, expressa sua intenção pragmática a um sujeito "tu" interpretante.

As principais visadas são:

- A visada de prescrição em que o eu comunicante tem autoridade para mandar o tu interpretante fazer algo.

- A visada de solicitação em que o eu comunicante deseja saber algo que o tu

\footnotetext{
${ }^{7}$ Do original: "s'instituent les contraintes qui déterminent l'enjeu de l'échange".
} 
interpretante está em posição de legitimidade para responder.

- A visada de incitação em que, embora o eu comunicante não tenha autoridade para prescrever, leva o tu interpretante a crer que o que ele manda fazer é benéfico.

- A visada de informação em que o eu comunicante, legitimado em sua posição e com conhecimento, apresenta fatos que o tu interpretante deve saber.

- A visada de instrução em que o eu comunicante, sabendo fazer algo e tendo autoridade para transmitir os procedimentos desse fazer, dá a conhecer esse saber-fazer ao tu interpretante que dele se apropria.

- A visada de demonstração em que o eu comunicante, ocupando certa posição de autoridade de saber, estabelece, por meio de provas, uma verdade ou uma hipótese sobre dado fenômeno, a qual o tu interpretante tem a capacidade e está em posição que lhe permite avaliá-la.

Vale ressaltar, porém, que as visadas não são "atos de fala" no sentido pragmático nem esquematizações abstratas de um texto, muito menos correspondem às funções de linguagem de Jakobson, uma vez que elas se situam bem antes da conceitualização e da configuração textual, não podendo, assim, constituir um princípio de tipologização dos textos.

As visadas são, assim, selecionadas conforme a finalidade da situação de comunicação. Charaudeau (2004) defende que o modelo em função das sequências textuais (modos de organização discursiva) não dá conta sozinho de explicar a classificação dos textos e que o modelo que contempla as visadas pode esclarecer melhor o funcionamento geral da tipologização. Tome-se como exemplo o gênero receita culinária, cuja situação comunicativa tem como visada a instrução, próprio ao nível situacional, e organiza-se no modo descritivo, próprio da organização discursiva, recorrendo a uma lista e léxico especializados para atender as marcas do "fazer", que se referem ao nível da configuração textual. De acordo com as palavras conclusivas de Charaudeau a respeito dos gêneros,

[...] pode-se dizer que, tendo diferentes níveis de produção-interpretação do discurso, cada um deles traz um princípio de classificação próprio: o nível situacional que permite reunir textos em torno das características do domínio de comunicação; o nível de restrições discursivas que deve ser considerado como o conjunto de processos que são solicitados pelas instruções situacionais para especificar a organização discursiva; o nível da configuração textual cujas recorrências formais são voláteis demais para tipificar definitivamente um texto, mas constituem pistas. Cada um desses princípios de classificação é legítimo e pode ser útil dependendo do objetivo da análise que se propõe seguir $\left(2001\right.$, p.23, tradução nossa). ${ }^{8}$

Como é possível depreender, dada a complexidade do fato linguageiro, a classificação dos gêneros não é uma tarefa simples, portanto, as análises devem

\footnotetext{
${ }^{8}$ Do original: [...] on peut dire qu'ayant affaire à des niveaux de production-interprétation du discours différents, chacun de ceux-ci apporte un principe de classement qui lui est propre : le niveau situationnel qui permet de rassembler des textes autour des caractéristiques du domaine de communication ; le niveau des contraintes discursives qui doit être considéré comme l'ensemble des procédés qui sont appelés par les instructions situationnelles pour spécifier l'organisation discursive ; le niveau de la configuration textuelle dont les récurrences formelles sont trop volatiles pour typifier définitivement un texte, mais en constituent des indices. Chacun de ces principes de classification est légitime et peut être utile selon l'objectif d'analyse que l'on se propose de suivre.
} 
priorizar o agrupamento de textos de acordo com as constantes que apresentam, recorrendo-se às combinações possíveis nos três níveis apresentados, sempre tendo como base a empiria linguageira.

Assim, um texto, para se materializar, precisa estar vinculado a quatro aspectos, a saber: uma finalidade/visada enunciativa, as identidades dos interactantes, um propósito temático, um dispositivo ou suporte. Todos esses aspectos são regidos por uma situação contratual que tende a regular a sobreposição e a articulação desses aspectos. Portanto, todo o ato de comunicação se origina de textos que são os objetos principais que relacionam duas instâncias: a da enunciação e a da recepção.

No que tange ao discurso da mídia informativa, "[...] a instância de enunciação é representada pelo produtor da informação, a instância de recepção pelo consumidor da informação e o texto pelo próprio produto midiático" (CHARAUDEAU, 1997, p. 86, tradução nossa $)^{9}$. Na próxima seção serão especificadas as propriedades do domínio midiático televisivo.

\section{A proposta tipológica de gêneros discursivos informativos ${ }^{10}$}

O suporte mediático abrange pelo menos três categorias: a jornalística (imprensa escrita), a televisiva e a radiofônica, para as quais a noção de gênero se torna problemática, pois elas se caracterizam pela transformação e heterogeneização das práticas de criação e recepção de discursos. A televisão, que é o suporte que interessa para esta discussão, apresenta uma materialidade semiótica multicomposicional e uma materialidade linguística híbrida.

Interessante notar que entre o programa televisivo em canal aberto ou fechado (modalidade padrão) e um programa televisivo na internet (Web TV), existem algumas diferenças: na primeira modalidade, um programa só poderá ser assistido no horário e dia previsto para tal, sem a possibilidade de retroceder ou repetir a visualização. Na segunda modalidade, os programas estão disponíveis para escolha, segundo o interesse e o tempo livre do espectador, com a possibilidade de repetir, voltar ou pular partes do evento. Além disso, os programas da Web TV se apresentam como um continuum menos flexível, diferente das tendências atuais dos canais televisivos padrões que constroem, por meio de decupagens e montagens, programas mais dinâmicos e híbridos, misturando diversos gêneros como nos talks shows (Caldeirão do Hulk, Programa da Eliana). Ou seja, quanto maior o dialogismo e a responsividade, sobretudo em situações comunicativas de auditório, maior a propensão de sobreposições de gêneros (entrevista, performance artística, relatos de vida e depoimentos, propaganda, noticiário, debates políticos etc.).

Os programas televisivos são classificados por rubricas ou seções que buscam constituir algumas categorias temáticas, tais como: entretenimento, informação, educação, ficção etc., entretanto, nem sempre essa divisão é favorecida devido à mesclagem dos gêneros.

De acordo com Charaudeau (2004, p. 27), o domínio midiático apresenta visadas

\footnotetext{
${ }^{9}$ Do orinal: [...] l'instance d'énonciation est représentée par le producteur d'information, l'instance de réception par le consommateur de l'information, et le texte par le produit médiatique lui-même.

${ }^{10}$ Esta seção é uma condensação e interpretação das ideias principais do texto de Charaudeau "Les conditions d'une typologie des genres télévisuels d'information" [As condições de uma tipologia dos gêneros televisivos de informação], de 1997.
} 
de informação e de incitação que levam a

\begin{abstract}
Tomar conhecimento do acontecimento para transformá-lo em notícia ("acontecimento narrado"), utilizando procedimentos descritivos e narrativos, às vezes objetivantes (credibilidade), às vezes dramatizantes (captação); explicar o acontecimento ("análise e comentário"), utilizando procedimentos argumentativos; produzir o acontecimento ("acontecimento provocado"), utilizando procedimentos de interação (debates, conversas, entrevistas). Os lugares atribuídos aos parceiros deste contrato (a identidade) determinam um quadro de tratamento enunciativo no qual a instância midiática deve se construir uma imagem de enunciador neutro, não implicado e distante, e deve construir uma imagem da instância destinatária devendo ser concernida (em nome da cidadania), tendo sensibilidade (em nome da natureza humana) e procurando compreender (em nome do espírito de simplicidade).
\end{abstract}

Os discursos midiáticos, portanto, comportam diversos gêneros secundários, segundo a proposta de Bakhtin (2000), uma vez que são interações institucionalizadas. A origem e a materialidade semiótica do objeto televisual é multicomposicional, pois compreende línguas faladas, línguas sinalizadas, línguas escritas, gestos, representações imagéticas etc. Charaudeau aponta os vários aspectos dessa tipologia discursiva, tais como:

- O tipo do modo discursivo - o suporte midiático se organiza em torno de três finalidades que estão ligadas ao tratamento de informação: relatar, comentar ou provocar um evento/acontecimento. Para atender às finalidades, são adotados procedimentos diferentes como a reportagem, o editorial ou o debate.

- O tipo de instância enunciativa - ligada à origem ou grau de intervenção do enunciador, no que tange à sua filiação interna (o repórter) ou externa (um convidado expert sobre o tema abordado).

- O tipo de conteúdo - relativo à natureza do tema que permite filtrar um tipo de modo discursivo e cruzá-lo com um macrodomínio. Por exemplo, um evento relatado pode envolver um evento político, esportivo ou cultural.

- As características do dispositivo cênico - diferentes suportes midiáticos impõem diferentes materialidades discursivas e, por consequência, implicam em especificidades próprias ao texto, tendendo a diferenciar os gêneros. Uma entrevista televisiva é diferente da entrevista na rádio ou na imprensa escrita, pois manifesta a materialidade da imagem dinâmica e presença corporal que as outras não possuem. Essa particularidade incide diretamente na mise-en-scène (encenação) que deve ser organizada de modo distinto.

Partindo dessas distinções, o domínio jornalístico televisivo é duplamente orientado, segundo sua referencialidade aos fatos públicos externos e sua interpelação, uma vez que mostra, relata e comenta esses fatos, de modo a causar efeitos de sentidos nos telespectadores. Os fatos são, assim, reconstruídos através das lentes que rompem com o evento em relação ao tempo, orientando uma interpretação pelo acréscimo de procedimentos de montagem, incrustação de elementos como imagens, modificação de sequências, ritmos e a inclusão de planos diferenciados e outros dados complementares.

Assim, o dispositivo televisual relaciona dois materiais semióticos: a parole (palavra) e a imagem. A palavra é suscetível de trabalhar os cinco tipos de enunciação, tais como a descrição (relatar o fato), a explicação (comentar o fato), o testemunho (testificar o fato), a proclamação (declarar performaticamente algo sobre o fato) e a contradição (apresentar os diferentes pontos de vista a respeito do fato). A imagem, 
segundo sua função referencial está associada à designação (o fato é mostrado), a figuração (o fato, que é muito complexo, pode ser simulado e reconstruído por analogia) e a visualização (o fato, que não pode ser visualizado, é representado virtualmente).

Diante dessas facetas do domínio televisivo, Charaudeau (1997) evidencia a sua complexidade, uma vez que as características apresentadas podem ser combinadas. $\mathrm{O}$ autor examina, então, os gêneros que ele considera serem a base da televisão: o jornal televisivo (JT), o debate e a reportagem, que serão discutidos a seguir.

O jornal televisivo é o gênero que integra formas distintas que podem conter anúncios, reportagens, resultados de enquetes, entrevistas, pequenos debates, análises de especialistas. Como já foi dito, de acordo com as finalidades, um evento pode ser relatado (ER), comentado (EC) e provocado (EP), assim, o JT pode abranger todos esses procedimentos discursivos. Charaudeau complementa:

Portanto, espera-se do JT uma decupagem do evento do mundo em pequenos pedaços, recorte que testemunharia o que aconteceu no espaço público, no curso de uma unidade de tempo, o cotidiano, unidade de tempo que seria o mesmo para todos os espectadores (1997, p.94, tradução nossa). ${ }^{11}$

Desse modo, o cotidiano do espaço público é fragmentado, de forma que se adapte a certas condições, tais como o papel do apresentador, que se caracteriza em uma interface entre o mundo referencial e o telespectador. No intuito de formar esse elo, o apresentador deve se apagar, construindo uma imagem de enunciador impessoal em relação aos fatos, assim, ele distribui turnos de fala a comentadores e especialistas externos que reforçam a "veracidade" do evento. Impõe-se, assim, um simulacro de verdade, encenado por esse "fazer-crer" que o evento previamente editado alimenta a partir da concatenação dos vários modos discursivos.

O debate televisivo, realmente muito comum e apreciado na cultura francesa, coloca vários convidados em torno do animador, promovendo a discussão de determinados temas sob vários pontos de vista diferentes. Os convidados são escolhidos pelos seus diferentes posicionamentos, representatividade ou autoridade em relação ao assunto abordado. O tema é escolhido de acordo com o público que se pretende atrair. Novamente, o autor chama a atenção para o fato de que o sistema democrático que se pretende defender ao trazer diferentes representantes sociais, também está, entretanto, no nível do simulacro, uma vez que as questões a serem discutidas são controladas pelo mediador do evento e que os atos discursivos são controlados de forma a produzir efeitos de sentido, de acordo com as visadas privilegiadas que se sobrepõem à visada de informação.

A reportagem busca explicar o estado de um fenômeno social de interesse geral que pode não estar relacionado diretamente à atualidade. Adotando um ponto de vista que segue o princípio de objetivação (distanciamento e generalização), propondo-se a incitar questões a respeito desse fenômeno por meio da reconstituição detalhada dos fatos, apoiada por vários recursos que imprimem credibilidade à finalidade informativa.

Dados esses embasamentos teóricos, na próxima seção será feita uma análise de alguns documentos multimídias da TV INES, a fim de investigar o comportamento dos gêneros discursivos informativos em língua de sinais.

\footnotetext{
${ }^{11}$ Do original: On attend donc du JT un découpage du monde événementiel en petits morceaux, découpage qui témoignerait de ce qui s'est passé dans l'espace public, au cour d'une unité de temps, le quotidien, unité de temps qui serait la même pour tous les spectateurs.
} 


\section{Análise de conteúdo multimídia da TV INES}

Ao ser constatada a problemática da escassez de estudos dos gêneros em Libras, vislumbrou-se o potencial analítico do acervo multimídia da TV INES. Porém, surgiu outra problemática, uma vez que as teorias existentes não contemplam o suporte webtelevisivo nem a materialidade cinésico-visual ${ }^{12}$. Deparou-se, assim, com a proposta semiodiscursiva de Charaudeau (1997, 2004) sobre os gêneros televisivos de informação voltados a análises da língua francesa e do suporte televisivo padrão.

Então, a questão posta é se esse arcabouço teórico-metodológico poderia ser adequado para atender ao objetivo geral deste estudo que consiste em investigar os gêneros informativos webtelevisivos em Libras.

Desmembrando o objetivo geral, foram delimitados os seguintes objetivos específicos: (a) apresentar a concepção semiodiscursiva de análises de gêneros (CHARAUDEAU, 2004); (b) discorrer sobre a proposta tipológica de gêneros televisivos informativos (CHARAUDEAU, 1997); e (c) explorar as possibilidades de análise documental de alguns videorregistros do acervo da TV INES, abordando, sobretudo, o telejornalismo, a reportagem e o debate.

Como percurso metodológico, adotar-se-ão os seguintes passos:

Para identificar os objetos a serem analisados, será usado o menu de categorias do site ou o motor de busca por palavras-chave. Depois de feita a seleção dos documentos multimídias que contêm os gêneros que interessam, eles serão analisados qualitativamente, observando a materialidade (língua oral-auditiva, língua cinésicovisual, língua escrita, imagens dinâmicas ou estáticas), a composição e níveis de organização, o tipo de modo discursivo implicado, o tipo de instância enunciativa, o tipo de conteúdo e as características do dispositivo cênico. Em suma, o trabalho transcorrerá a partir do método conceitual-analítico de acordo com as categorias e os pressupostos da perspectiva semiodiscursiva apresentada nas seções 2 e 3 .

A plataforma televisiva do INES apresenta em sua página inicial o item "programas" em seu menu. Ao abri-lo, rubricas como educação, entretenimento, especial, filmes/documentários, humor, infantil e jornalismo são listadas. Dentro de cada uma, estão listados os programas, conforme o quadro 1.

Fonte: Realizado pela autora, a partir dos dados contidos no menu do site

\begin{tabular}{|c|c|c|}
\hline & \multicolumn{2}{|c|}{ ronte: Realizado pela autora, a partir dos dados contidos no menu do site } \\
\hline & Rubricas & Programas \\
\hline \multirow[b]{9}{*}{ Programas da TV INES } & \multirow{5}{*}{ Educação } & A história das coisas \\
\hline & & A vida em Libras \\
\hline & & Aula de Libras \\
\hline & & Ligado em saúde \\
\hline & & Manuário \\
\hline & \multirow[b]{4}{*}{ Entretenimento } & Café com Pimenta \\
\hline & & Mão na bola \\
\hline & & Momento ambiental \\
\hline & & O que me faz bem \\
\hline
\end{tabular}

\footnotetext{
${ }^{12}$ A expressão cinésico-visual corresponde ao tipo de modalidade de produção e recepção das línguas de sinais e dos gestos. Outros autores usam as expressões gesto-visual ou espaço-visual como correlatas.
} 


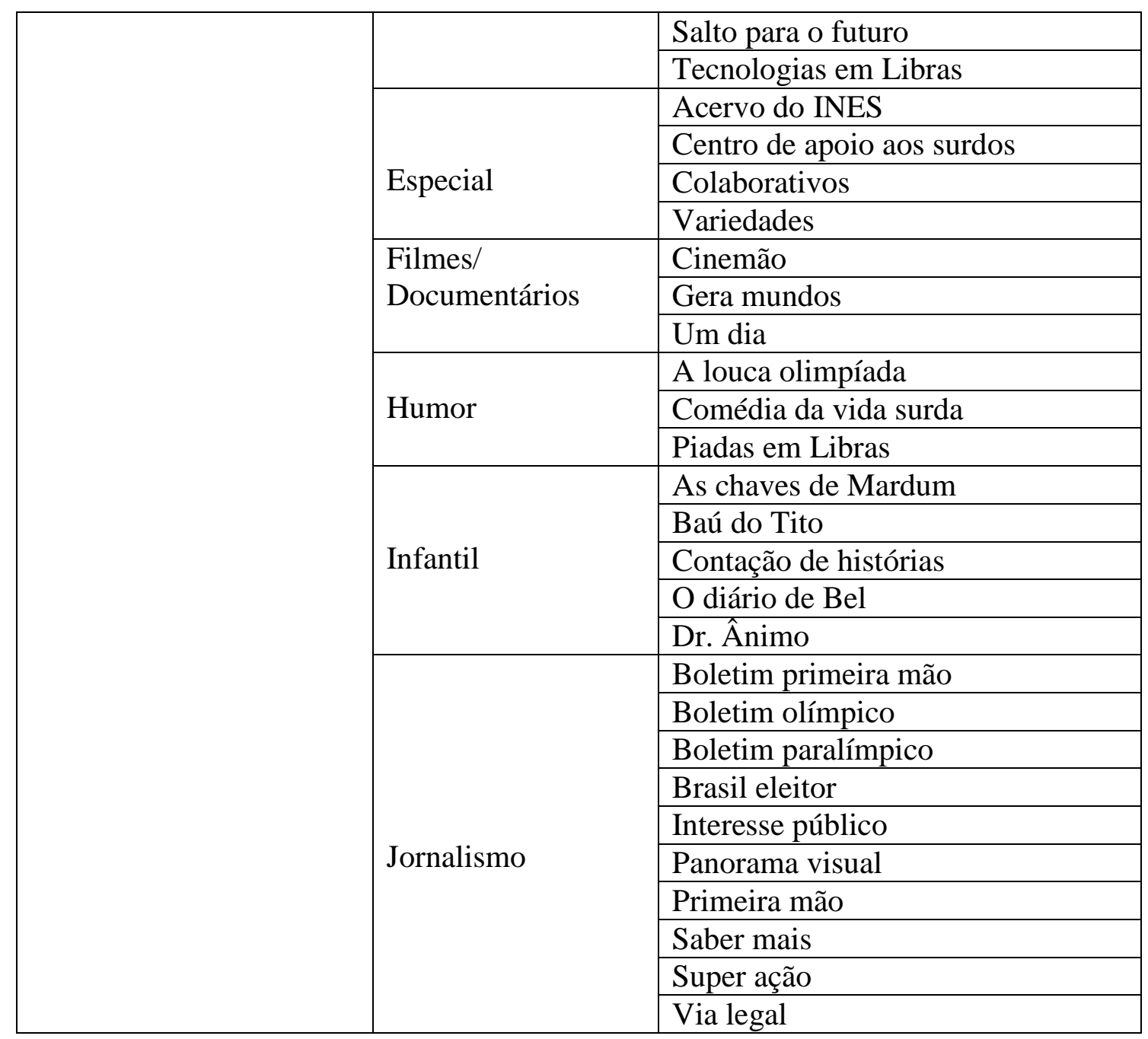

Quadro 1 - Categorias da programação da TV INES

Charaudeau (1997, 1999, 2001) já advertiu sobre a problemática das classificações dos gêneros, pelo fato de serem caracterizados por sua heterogeneidade. Essa dificuldade de classificação pode ser observada na composição e na organização dos programas da TV INES, uma vez que as categorias, os gêneros e as sequências discursivas são complexas.

Não há dúvidas de que a maioria dos programas da TV INES apresenta uma visada de informação, em que o eu comunicante (produtor da informação), legitimado em sua posição e com conhecimento necessário, apresenta fatos que o tu interpretante (o consumidor da informação) deve saber. Entretanto, o programa "Aula em Libras" apresenta uma visada de instrução, visto que o eu comunicante, tendo o conhecimento da Libras, aproveita o espaço para transmitir esse saber ao tu interpretante, no papel de espectador/aprendente.

Os programas "Boletim olímpico", "Boletim paralímpico" e "Mão na bola" poderiam estar em uma seção de esportes. Entretanto, o programa de variedades "Vida em Libras, dedicou um de seus eventos à capoeira, que é um esporte. Aliás, esse programa aborda diferentes eventos relatados que poderiam pertencer a diferentes categorias como entretenimento, esporte, cultura, utilidade pública, literatura infantil 
etc.

Outro exemplo é o programa "Um Salto para o Futuro" que foi inserido na seção de entretenimento, embora, devido às suas características, ele pudesse estar vinculado à seção Educação também. Da mesma forma, o programa "Via legal", que é produzido pelo Centro de Produção de Programas da Justiça Federal para a Televisão (CPJus) em parceria com outros conselhos, que tem por objetivo cobrir várias medidas da Justiça Federal em todo o Brasil, está inserido na seção "jornalismo". Porém, ele poderia estar vinculado à seção "Especial" que hoje abrange apenas alguns documentos institucionais, mas poderia incluir boletins informativos de diferentes domínios de interesse público como justiça, saúde, eleitoral, entre outros.

Esses exemplos mostram a dificuldade de organizar determinados objetos em categorias por causa do caráter multicomposicional e multitemático dos programas televisivos. Apesar de que, em se tratando de plataformas Web, esse problema é contornado com a disponibilidade do espaço de busca, onde é possível digitar palavraschave que correspondem aos assuntos desejados. No entanto, esse recurso só está disponível em língua escrita do português e não em Libras ou escrita de sinais, por exemplo.

Para iniciar as análises, foi escolhido um documento multimídia do programa "Panorama Visual" que está associado à seção "jornalismo". O evento, cujo título é "emprego para mães", pode ser caracterizado como reportagem. A página contém o vídeo do evento, acompanhado de um resumo sobre o tema da recolocação de mulheres no mercado após a maternidade, logo abaixo. Ao lado do resumo, há uma caixa de texto com alguns dados do documento, tais como: o número de visualizações (141 na data de confecção deste artigo), a duração do videorregistro (00:13:33), o ano (2019), o produtor (Null), a data de publicação (8 de maio de 2019) e a categoria (informação, jornalismo, Panorama Visual).

Nota-se que o programa abrange os três modos discursivos descritos por Charaudeau: $\mathrm{O}$ evento relatado (ER), o evento comentado (EC) e o evento provocado (EP). O fenômeno social "emprego para mães" é abordado pela repórter surda (Clarissa Guerretta), que inicia o programa relatando as dificuldades do retorno ao mercado de trabalho por parte das mulheres após a maternidade. A estratégia de apresentar-se diante de cenários externos ao estúdio enquadra o tema dentro da perspectiva de fato social.

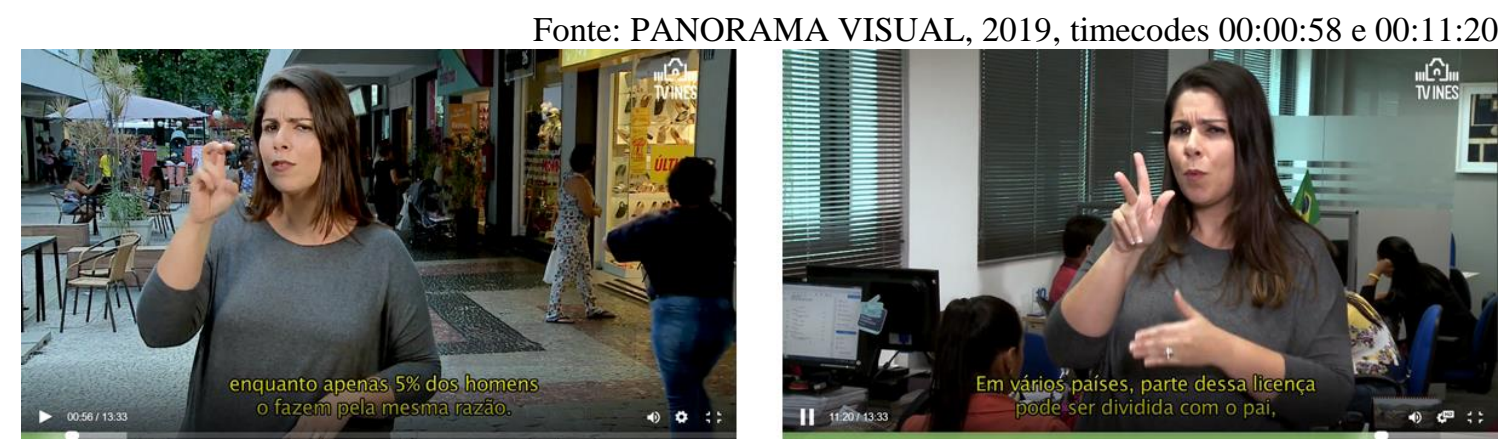

Figura 1 - Cenários externos ao estúdio de gravação

A figura 1 mostra os tipos de cenários externos (fora do estúdio) que podem ser em ambientes abertos ou fechados. Outros elementos que serão sobrepostos, tais como imagens estáticas e dinâmicas, remetem a um simulacro da vida cotidiana (Figura 2, timecode 00:10:10). Isso geralmente é feito quando a materialidade discursiva é falada 
em português. Nesse caso, a voz da enunciadora é sobreposta pela imagem da intérprete e a tela é dividida, apresentando outras materialidades semióticas simultaneamente, mas rapidamente, a fim de não romper com a referência da convidada que enuncia.

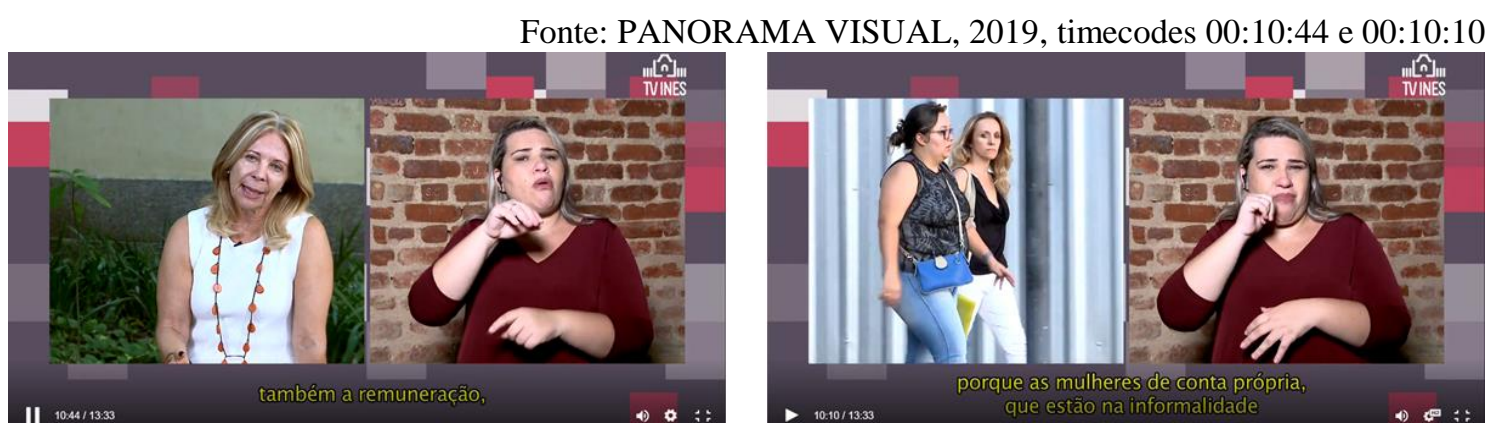

Figura 2 - Sobreposição de diferentes materialidades semióticas

A figura 2 apresenta as possibilidades de divisão de tela, em que intérprete e convidada são postas lado a lado. A sequência pode ser complementada com imagens estáticas ou dinâmicas, nesse caso, o enunciado da convidada fica marcado pela presença da intérprete.

Para dar veracidade às informações sobre o tema, convidadas mulheres comentam o assunto, na posição social de especialistas, pesquisadoras ou mesmo agentes sociais que vivenciaram a situação. As participações em português falado das especialistas não-surdas Daniela Dantas, gerente de desenvolvimento organizacional, Lena Lavinas, professora de economia da Universidade Federal do Rio de Janeiro, e a mãe Diana Quintella, consultora de desenvolvimento, são traduzidas para a Libras pela intérprete Daniela Abreu. Todos os enunciados são legendados e os elementos sonoros acompanhados de tradução audiovisual.

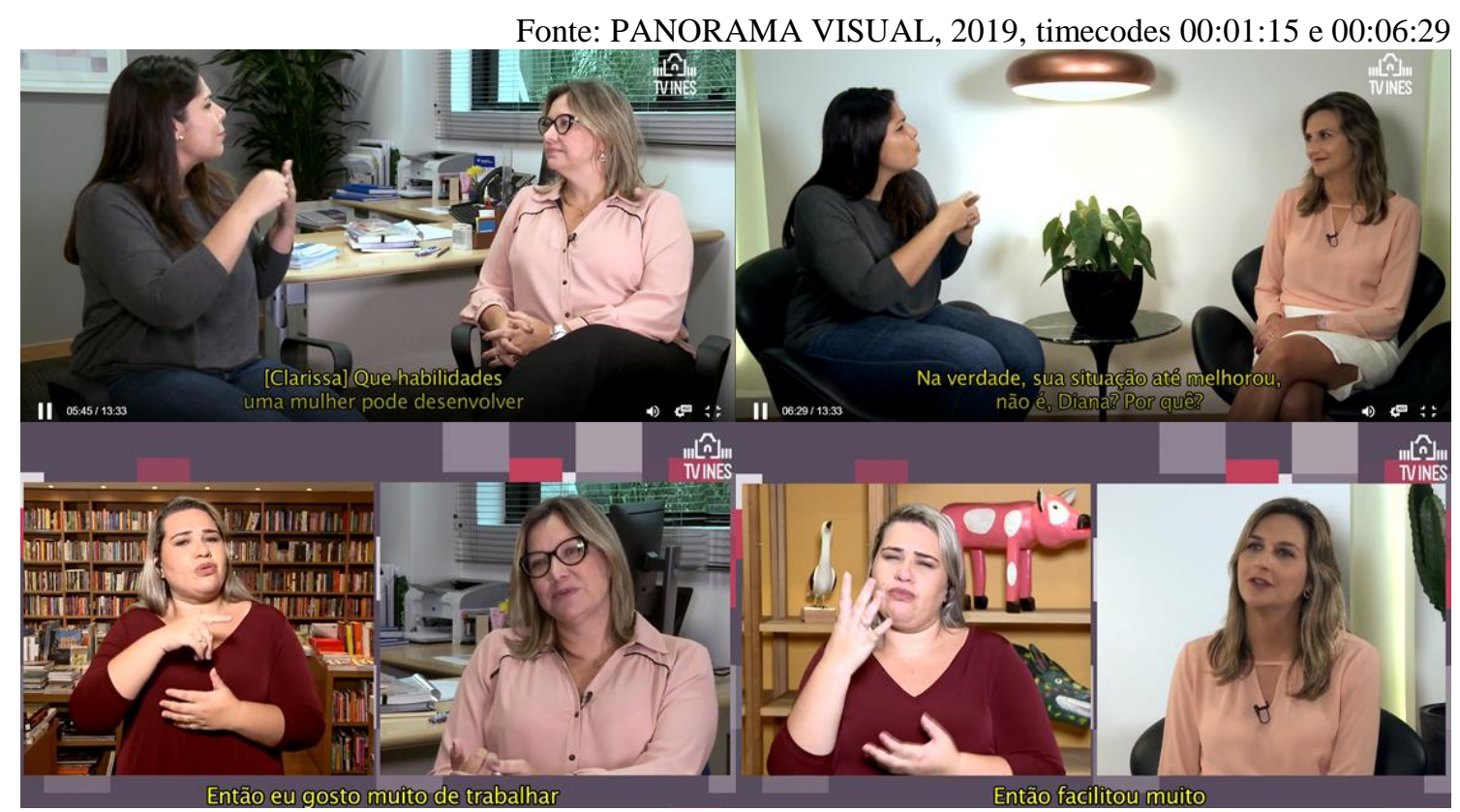

Figura 3 - Entrevistas com convidadas não-sinalizantes mediadas por intérprete.

A figura 3 apresenta duas situações de entrevistas com convidadas não- 
sinalizantes em que a instância discursiva é mediada por intérprete que, embora não apareça na primeira cena onde estão a repórter e as convidadas, supõe-se que esteja presente em um outro espaço dos locais de gravação, uma vez que a apresentadora é surda e as convidadas não enunciam em língua de sinais.

Entre uma convidada e outra, a repórter apresenta dados estatísticos e pesquisas sobre o tema (figura 1, timecode 00:11:20). Suas participações são, assim, intercaladas, dando a noção de decupagem e bricolagem, proporcionada pela edição do conteúdo. Entretanto, as entrevistas com duas convidadas sinalizantes apresentam restrições específicas à materialidade discursiva em língua de sinais, uma vez que a sobreposição de materialidades visuais poderia colocar elementos de mesma natureza semiótica em competição.

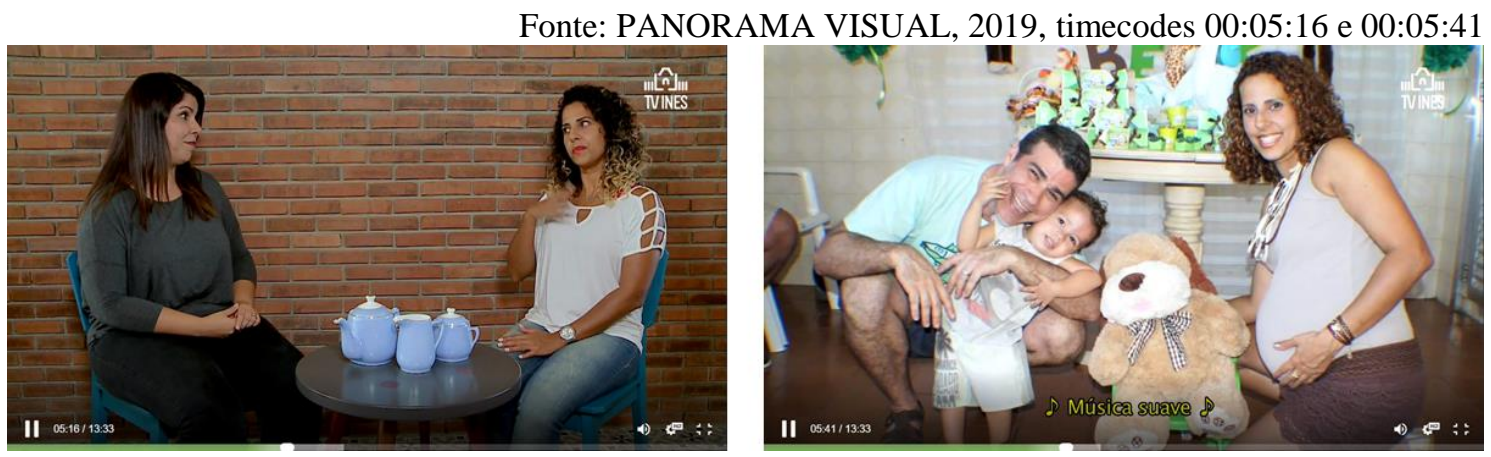

Figura 4 - Entrevista sinalizada com elementos semióticos sequenciais

Os elementos complementares, nesse caso, são concatenados sequencialmente, conforme a figura 4 (timecode 00:05:41). Para as participações sinalizadas dos depoimentos de Keila Sampaio, pedagoga e mãe (figura 4), e de Érika Paula, professora surda e mãe (figura 5), bem como da repórter, são disponibilizadas locuções em voice over.

Um jogo de abertura e fechamento de planos do objetivo pode ser realizado. Um grande plano pode ser usado, sobretudo quando enunciado na materialidade da língua de sinais, como está representado na figura 5.

Fonte: PANORAMA VISUAL, 2019, timecodes 00:08:23 e 00:08:34
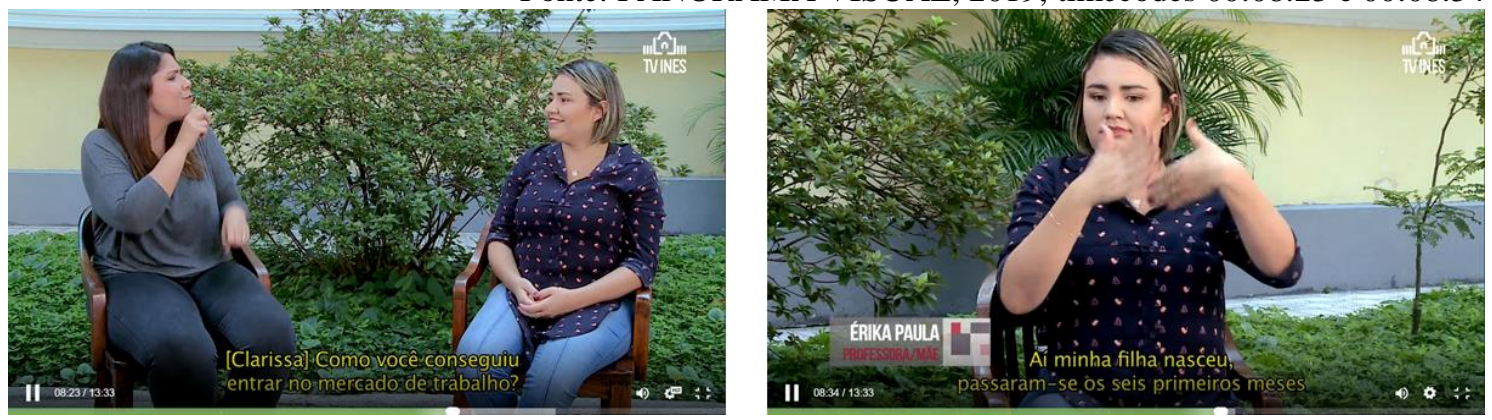

Figura 5 - Entrevista sinalizada com grande plano da entrevistada

Nota-se, assim, que esse recurso é explorado quando o(a) convidado(a) é sinalizante, uma vez que não é necessária a mediação de intérprete e que a narração em voice over e a legenda escrita são materialidades compatíveis que permitem a simultaneidade.

Pode-se, assim, concluir que o programa "Panorama Visual" apresenta a visada 
da informação e possui uma organização multicomposicional, ou seja, está organizado em torno dos três modos discursivos, pois relata, narra, comenta e provoca eventos; é composto por várias materialidades que se sucedem ou mesmo se sobrepõem; abrange a reportagem, que, por sua vez, apresenta subgêneros, tais como a entrevista, o editorial, o depoimento, o relato pessoal que giram em torno de temas específicos.

Os próximos documentos analisados pertencem ao repertório do webjornalismo, especificamente do programa "Primeira Mão", que apresenta as principais notícias do Brasil e do mundo, abrangendo assuntos da política, economia, serviços, curiosidades e dicas de cultura e lazer.

No menu de organização das categorias, ele se encontra na rubrica "jornalismo". Esse programa se aproxima do telejornalismo que foi descrito por Charaudeau (1997), uma vez que, seguindo o molde dos telejornais tradicionais, apresenta um cenário com dois apresentadores que relatam notícias da atualidade nacional e internacional.

As páginas onde os videorregistros estão inseridos, da mesma forma que o programa anteriormente analisado, contêm as informações de base sobre o conteúdo. Os apresentadores, cada um a seu turno, fazem a chamada da notícia que será tratada. Em seguida, a informação passa a ser narrada em voice over e traduzida por um intérprete de Libras que compartilha a tela com outras materialidades semióticas visuais.

Fonte: PRIMEIRA MÃO, 2019b, timecodes 00:07:03 e 00:01:05

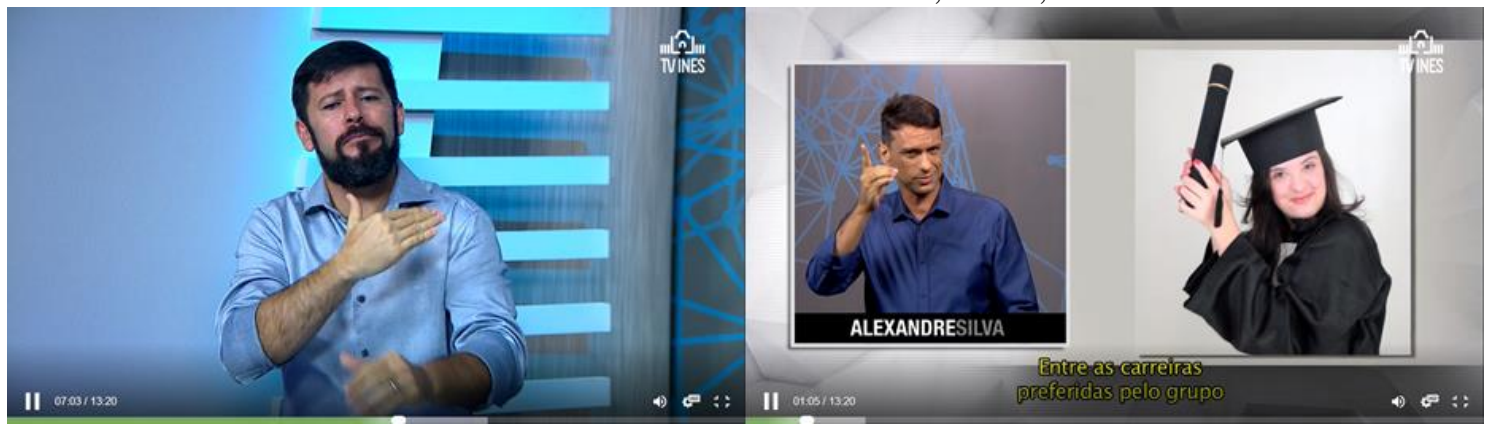

Figura 6 - Plateau de webjornalismo

A figura 6 oferece um exemplo de chamada feita por um dos apresentadores, seguida pela notícia em português falado que é traduzido por intérprete de língua de sinais. O programa também traz informações sobre eventos culturais e artísticos, além de ter um quadro de entrevistas que pode acontecer em cenário interno ou externo. A figura 7 apresenta uma entrevista em cenário interno, em que o entrevistado comparece no estúdio, e uma entrevista em cenário externo, em que a apresentadora sai do estúdio para encontrar a pessoa entrevistada.

Fonte: PRIMEIRA MÃO, 2019a, timecodes 00:01:46 e 00:14:14

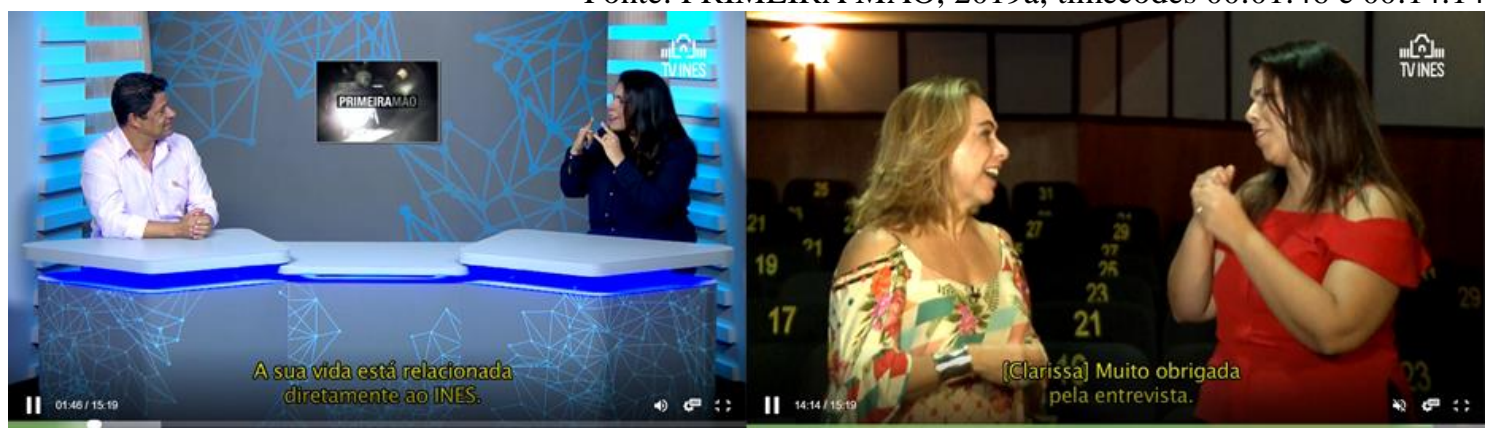


No primeiro exemplo da figura 7, trata-se do novo diretor-geral do Instituto Nacional de Educação de Surdos do Rio de Janeiro, o Sr. Paulo Bulhões, convidado para apresentar seu plano de ação na nova função. No segundo exemplo, a atriz Cissa Guimarães foi procurada para falar da sua peça "Doidas e Santas", que passou a ser acessível em Libras, à seção do webjornal chamada de Agenda Cultural.

O telejornalismo, assim, parece ser uma categoria mais genérica, uma vez que é organizado de modo multicomposicional e que abrange, além da própria reportagem, entrevistas, notícias, avisos, chamadas públicas etc. Na configuração francesa, ele pode abranger inclusive os debates. Portanto, parece que a própria divisão de Charaudeau (1997) apresenta fragilidades por causa das diversas possibilidades que os dados empíricos apresentam.

No que concerne os debates, a Web TV do INES oferece um programa chamado "Um Salto para o Futuro" que, na verdade, é um programa externo de debates sobre educação que é traduzido para a Libras e disponibilizado na plataforma. Trata-se de um programa dirigido à formação continuada de professores e de gestores da educação básica, sendo o único programa que apresenta o subgênero debate. Não obstante, por se tratar de um projeto externo, poucas vezes haverá o protagonismo surdo nas discussões, uma vez que os convidados são, na sua maioria, não-surdos.

A figura 8 contém duas situações de debates. Os convidados enunciam em português, por isso a mediação das intérpretes é primordial.

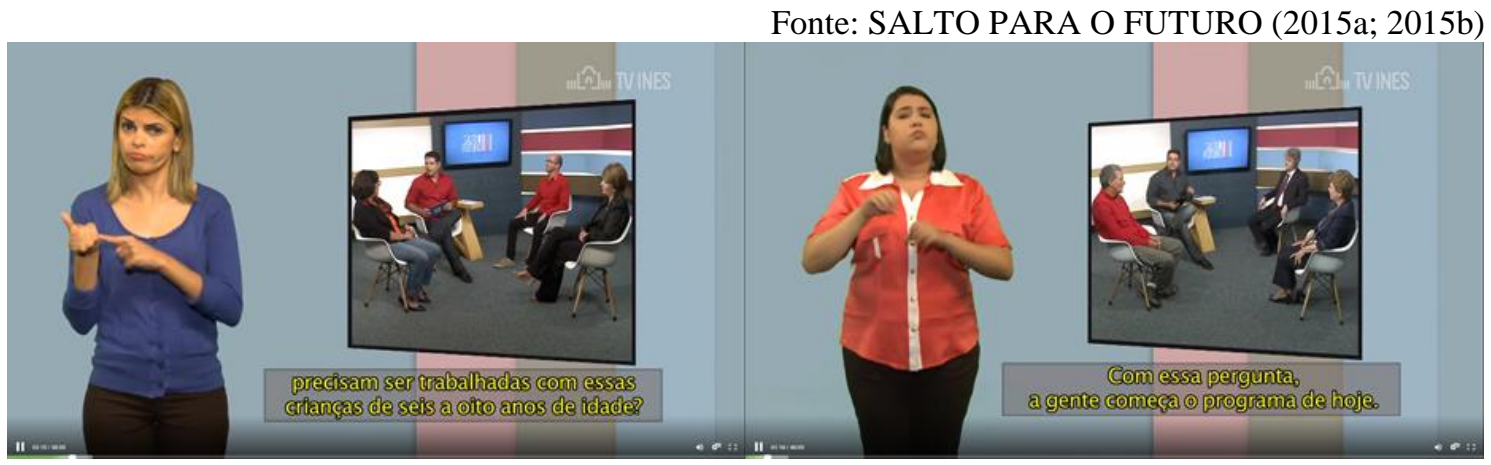

Figura 8 - Dois debates do programa Salto para o futuro

Outra particularidade foi identificada quando, ao digitar a palavra "debate" no motor de busca do site, o resultado lista vários documentos que apresentam essa rubrica, entretanto, com exceção desse programa, as outras ocorrências são, na verdade, entrevistas. Nesse caso, é muito mais comum a presença de convidados surdos, garantindo, assim, a representatividade da comunidade surda.

Com base nesses exemplos, pode-se depreender que o subgênero entrevista está presente em vários documentos do acervo midiático e que a reportagem pode abranger esse subgênero. Por outro lado, reportagens e entrevistas são muito recorrentes no telejornalismo, o que demonstra haver uma certa hierarquia nessa classificação. Outra evidência é que o acervo da TV INES contém os três tipos de evento ou acontecimento - evento relatado, evento comentado e evento provocado - que formam a estrutura de vários programas.

Vale, portanto, refinar a análise no intuito de demarcar a diferença estabelecida por Charaudeau (1997) entre gêneros e modos de organização discursiva (sequências 
textuais). Essa análise permite constatar que o autor tem razão ao defender que as ocorrências formais são voláteis demais para tipificar um texto. A figura 9 oferece um exemplo que pode confirmar o argumento do autor.

Fonte: PRIMEIRA MÃO, 2019c, timecodes de 00:08:46 a 00:08:58

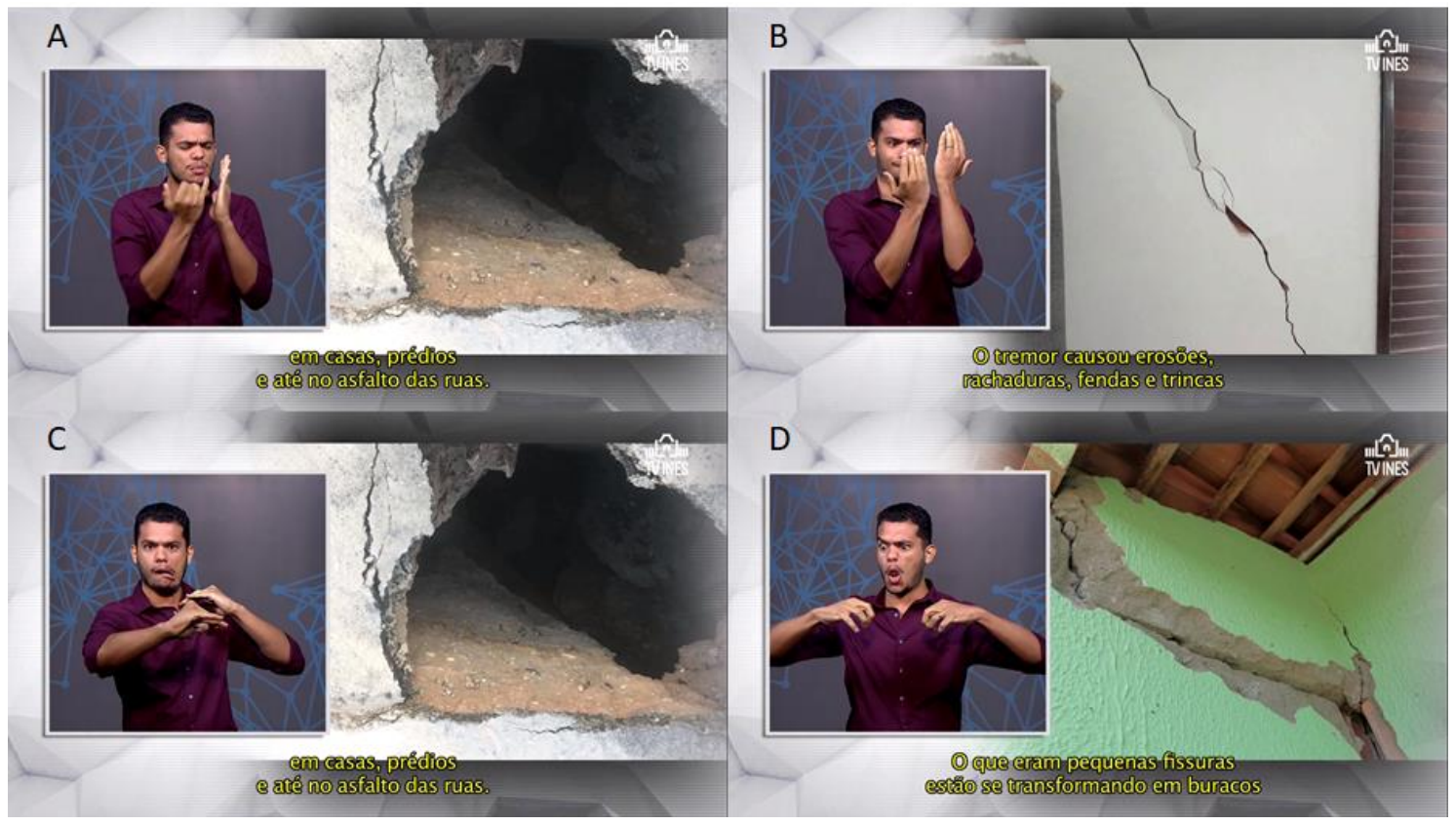

Figura 9 - Exemplo de modo discursivo descritivo

De fato, por ser uma língua com característica visual, a Libras "ilustra" ou "demonstra" o conteúdo semântico. As sequências da figura 9 remetem a uma notícia sobre um tremor de terra na cidade de Maceió. O intérprete precisou descrever o estado dos prédios e das ruas após o fenômeno natural. Os termos "erosões", "rachaduras", "fendas" e "trincas" nas "casas", "prédios" e "asfaltos" precisaram ser descritos por meio de configurações metonímicas (classificadores) - mão(s) espalmada(s) na vertical para paredes (sequências A e B da figura 9) e mãos em concha ou garras com palmas voltadas para baixo para solos (sequências C e D da figura 9) e expressões faciais qualificativas associadas. Assim, quanto maior o dano provocado, maior a ênfase da expressão facial e a dimensão dos movimentos executados pelos articuladores principais (mãos e braços).

Efetivamente, sequências textuais descritivas são muito comuns em vários gêneros da Libras e geralmente fazem uso de configurações metonímicas, que é uma das ocorrências formais de grande iconicidade (CUXAC, 1998, 2000). Esse uso é solicitado sempre que algum aspecto, característica ou estado de um fenômeno ou objeto necessita ser especificado. Portanto, a organização textual e os modos discursivos parecem estar muito mais restringidos às especificidades do evento a ser relatado ou comentado do que ao gênero propriamente dito. Além disso, os modos de organização discursiva se misturam, por isso, é raro que um texto seja unicamente narrativo ou descritivo porque essas sequências são partes composicionais com as quais se organiza a estrutura de um texto, e elas podem ser intercaladas em um mesmo gênero.

Tome-se como exemplo o gênero entrevista, cuja situação comunicativa começa pela visada de solicitação (o entrevistador deseja saber algo que o entrevistado está em posição de legitimidade para responder) que pode, dependendo do que se quer saber, do 
tema e da intenção do entrevistado, encadear outras visadas como a prescrição, a incitação, a informação, a instrução e a demonstração. A partir disso, os textos dos enunciadores podem organizar-se discursivamente no modo argumentativo, descritivo, narrativo, expositivo, injuntivo (explicativo) e configurados segundo as propriedades formais para que mantenham a coesão entre esses modos.

Para finalizar esta seção, é possível afirmar que os documentos multimídias da TV INES fornecem dados suficientes para testar a proposta semiodiscursiva e tipológica de Charaudeau (1997; 2004), porém, a Web TV e a materialidade cinésico-visual, que não foram contempladas pelo autor, possuem algumas restrições específicas quanto ao suporte e ao modo de produção e recepção discursiva. Essas questões serão discutidas à guisa de conclusão na próxima seção.

\section{Considerações finais}

Este estudo teve origem com a seguinte questão: Os documentos multimídias da TV INES podem ser analisados de acordo com a proposta de Charaudeau (1997; 2004), apesar de esse autor não ter abordado a Web TV nem a materialidade sinalizada? A partir dessa questão, traçou-se o objetivo geral de investigar os gêneros informativos webtelevisivos em Libras, submetendo-os aos critérios de análise semiodiscursiva desse arcabouço teórico-metodológico. Assim, buscou-se identificar os conteúdos multimídas do acervo da TV INES que apresentassem os três gêneros discutidos por Charaudeau (2004): o jornal televisivo, a entrevista e o debate.

Após as análises, constatou-se que os pressupostos teóricos de Charaudeau $(1997,2004)$ podem ser aplicados tanto à materialidade oral auditiva quanto à cinésicovisual. De fato, os modos de produção discursiva são restringidos mais pelo suporte, pela situação comunicativa e pelas finalidades do que pelas especificidades linguísticas propriamente ditas. Nesse sentido, a noção de parole abrange as duas modalidades.

Com Libras também é possível relatar, explicar, testemunhar, proclamar e contradizer. Isso porque a base de constituição das comunidades implica memórias que são psico-sócio-comunicacionalmente construídas e compartilhadas. Portanto, os surdos e não-surdos sinalizantes inscrevem-se no mundo dos signos em suas circunstâncias sócio-históricas, dotando-se de gêneros, significando suas intenções e regulando seus modos de dizer em língua de sinais, de acordo com os lugares e os papéis sociais que ocupam, do mesmo modo que fazem os não-sinalizantes com as línguas faladas.

Basicamente, são as dimensões da ancoragem social, da natureza comunicacional, das atividades linguageiras e das características formais implicadas na construção dos gêneros que devem ser levadas em consideração. A materialidade linguística não interfere na aplicação dos princípios teóricos aqui fundamentados, embora seja importante destacar que as especificidades, diferenças e efeitos de modalidade (MEIER, 2002) da materialidade escrita, sinalizada ou falada pode apresentar quando associadas a outras materialidades semióticas na composição dos gêneros.

Constatou-se, portanto, que no suporte webjornalístico, a Libras pode ser sobreposta à fala e à escrita, mas a tela de um videorregistro precisa, necessariamente, ser dividida quando se deseja mostrar um discurso em Libras e uma imagem estática ou dinâmica simultaneamente. A voz humana, por outro lado, permite a simultaneidade com qualquer outra materialidade semiótica, menos com as que são da mesma natureza, 
ou seja, sonora.

Pelo fato de a TV INES ter como objetivo principal a acessibilidade dos agentes surdos à informação, a necessidade do discurso mediado por intérprete de língua de sinais é mais recorrente, entretanto, o discurso em língua de sinais assegura, de forma mais efetiva, a representatividade surda.

$\mathrm{O}$ apresentador surdo ou o intérprete de Libras é a interface entre o mundo referencial e o telespectador surdo ou ouvinte. Os eventos desse mundo referencial são relatados, comentados ou provocados por meio de várias estratégias discursivas e linguageiras.

Outra especificidade imposta pela materialidade cinésico-visual incide sobre a dificuldade do apagamento desse profissional, pois a construção de uma imagem de enunciador impessoal é dificultada pela presença corporal intrínseca à língua de sinais. Dito de outra forma, enquanto o falante pode dissimular suas expressões corporais, faciais e modalizações prosódicas, o sinalizante constitui, com esses elementos, a materialidade de sua língua, ao ponto que se as dissimulasse, poderia desfavorecer a compreensão dos interpretantes. A figura 9 apresentou um exemplo que ilustra perfeitamente esse efeito ligado à materialidade da Libras, pois, a fim de transmitir as proporções do evento relatado, foi preciso qualificar determinadas formas com expressões faciais específicas.

Contudo, essa especificidade imposta pela modalidade não compromete, de modo nenhum, a possibilidade de análise dos gêneros textuais em língua de sinais de acordo com a perspectiva semiodiscursiva. Com efeito, os fatos linguageiros na materialidade cinésico-visual estão sujeitos aos princípios, mecanismos e restrições da situação comunicativa, assim como outras materialidades linguísticas. Ou seja, os fatos linguageiros estão todos condicionados aos princípios de alteridade, de influência, de regulação e pertinência; estão também ordenados discursivamente e restringidos ao lugar e às identidades das instâncias enunciativa e interpretativa. Os gêneros em língua de sinais cumprem, assim, as mesmas finalidades que os gêneros escritos ou oraisauditivos.

Os gêneros televisivos de informação da plataforma da TV INES, portanto, são construídos a partir da transformação do conhecimento sobre os fatos sociais, fazendo uso de procedimentos discursivos diferentes, adequando as formas e os modos de dizer à ancoragem social da instância destinatária. Os documentos analisados apresentaram uma heterogeneidade que tornou complexa a organização das categorias, evidenciando que o telejornal, a reportagem e o debate não se encontram dentro do mesmo nível hierárquico, uma vez que o telejornal pode conter a reportagem e o debate.

Grosso modo, este trabalho embrionário se mostra importante, haja vista que amplia a aplicabilidade da perspectiva semiodiscursiva para o webjornalismo e para os gêneros em língua de sinais. Essa base teórica permitiu uma reflexão mais consciente sobre a natureza dos gêneros nesse tipo de suporte e de como eles funcionam na materialidade cinésico-visual. Os resultados mostraram a validade, mas também apontaram as fragilidades das categorias do arcabouço teórico adotado, exigindo, portanto, uma continuidade em futuras investigações para as quais este trabalho oferece subsídios muito relevantes.

\section{REFERÊNCIAS}


ACOSTA PEREIRA, Rodrigo. Gêneros do discurso - experiências psicossociais tipificadas. Revista Letra Magna, Revista Eletrônica de Divulgação Científica em Língua Portuguesa, Lingüística e Literatura, São Paulo, vol. 4, n. 8; p.1-17, 2008.

BAKHTIN, Mikhail. Os Gêneros do Discurso. In: A Estética da Criação Verbal. São Paulo: Martins Fontes, 2000. p. 279-326.

CHARAUDEAU, Patrick. Une analyse sémiolinguistique du discours. Langages, Lyon, n. 117, p. 96-111, 1995.

Les conditions d'une typologie des genres télévisuels d'information. Réseaux, Paris, v. 15, n. 81, p. 79-101, 1997.

. Une problématique des genres. De la situation à la construction textuelle. In: site do autor, rubrica livros, artigos e publicações, 1999. Disponível em: http://www.patrick-charaudeau.com/Une-problematique-des-genres-De-la.html. Acesso em 14 maio 2019.

Visées discursives, genres situationnels et construction textuelle. Analyse des discours: Types et genres. Éd. Universitaires du Sud, Toulouse, 2001. Disponível em: http://www.patrick-charaudeau.com/Visees-discursives-genres,83.html. Acesso em 16 maio 2019.

Visadas discursivas, gêneros situacionais e construção textual. In:

MACHADO, Ilda; MELLO, Renato. (org.). Gêneros: Reflexões em Análise do Discurso. Belo Horizonte: NAD/FALE/UFMG, 2004. p. 13-41.

Uma análise semiolingüística do texto e do discurso, In: PAULIUKONIS, Maria Aparecida; GAVAZZI, Sigrid (Orgs.) Da língua ao discurso: reflexões para o ensino. Rio de Janeiro: Lucerna, 2005. p. 11-29.

Discurso das Mídias. São Paulo: Contexto, 2006.

Los géneros: una perspectiva socio-comunicativa. In: SHIRO, Martha; CHARAUDEAU, Patrick; GRANATO, Luisa (eds.). Los géneros discursivos desde múltiples perspectivas: teorias y análisis. Madrid: Lingüística Iberoamericana; Frankfurt: Vervuert, 2012.

CUXAC, Christian. Constructions de références en langue des signes française : les voies de l'iconicité. Sémiotiques, Paris, v. 15, p. 85-105, 1998.

La Langue des Signes Française: les Voies de l'Iconicité, Paris: Ophrys, 2000.

MAINGUENEAU, Dominique. Análise de Textos da Comunicação. São Paulo: Cortez, 2001.

Diversidade dos Gêneros do Discurso. In: MACHADO, I. L. \& MELLO, R. (orgs.). Gêneros: Reflexões em Análise do Discurso. Belo Horizonte: 
NAD/FALE/UFMG, 2004.

MEIER, Richard. Why different, why the same? Explaining effects and non-effects of modality upon linguistics structure in sign and speech. In: MEIER, Richard;

CORMIER, Kearsy; QUINTO-POZOS, David. Modality and structure in signed and spoken languages. Cambridge: Cambridge University Press, 2002.

PANORAMA VISUAL. Emprego para mães. In: TV INES, 2019. Disponível em: http://tvines.org.br/?p=19640. Acesso em 16 maio 2019.

PRIMEIRA MÃO. Webjornalismo, edição 14 fevereiro de 2019. In: TV INES, 2019a. Disponível em: http://tvines.org.br/?p=19307. Acesso em 16 maio 2019.

Webjornalismo, edição 16 de maio de 2019. In: TV INES, 2019b. Disponível em: http://tvines.org.br/?page_id=14485. Acesso em 16 maio 2019.

Webjornalismo, edição 14 de março de 2019. In: TV INES, 2019c. Disponível em: http://tvines.org.br/?p=19414. Acesso em 16 maio 2019.

SALTO PARA O FUTURO. Ensino médio: oportunidades e desafios, debate. In: $T V$ INES, 2015a. Disponível em: http://tvines.org.br/?p=13100. Acesso em 16 maio 2019.

Geometria, debate. In: TV INES, 2015b. Disponível em:

http://tvines.org.br/?p=7527. Acesso em 16 maio 2019. 